\section{Volume $3 \cdot$ Nomor 2 • Februari 2020 \\ Pege (Hal.) : $12-22$}

(C) Universitas Pamulang

JL.Surya Kencana No.1 Pamulang, Tangerang Selatan - Banten

Telp. (021) 7412566, Fax (021) 7412491 Email : jurnalmarketing.unpam@gmail.com

\title{
Pengaruh Kualitas Produk dan Harga Terhadap Keputusan Pembelian
}

\author{
Nurmin Arianto ${ }^{1}$, Giovanni ${ }^{2}$ \\ Universitas Pamulang. dosen01118@unpam.ac.id
}

\begin{abstract}
Penelitian ini bertujuan untuk mengetahui pengaruh kualitas produk dan harga baik secara parsial maupun secara simultan terhadap keputusan pembelian. Ini merupakan penelitian asosiatif. Populasi dalam survei ini pembeli yang membeli produk butik dengan ukuran sampel yang digunakan oleh 92 pengguna menggunakan metode random sampling. Ketika mengumpulkan data menggunakan kuesioner, kuesioner pada metode distribusi, metode analisis data yang digunakan adalah analisis regresis berganda linier, koefisien korelasi sesaat, koefisien determinasi dan kriteria (uji t F) untuk suatu produk. Analisis menunjukkan bahwa ada efek parsial dan simultan pada keputusan pembelian yang muncul dari koefisien regresi linier berganda $Y=16,621+0,538 X 1+$ $0,170 \mathrm{X} 2$ + e. Seperti dapat dilihat dari tabel interpretasi, koefisien korelasi massa adalah 0,60-0,79 dengan korelasi kuat. Hasil koefisien determinasi mencapai $62,1 \%$ dari nilai KD, menunjukkan bahwa kualitas dan dampak harga pada keputusan konsumen untuk membeli di butik adalah $62,1 \%$, dan sisanya dipengaruhi oleh faktor lain yang belum dieksplorasi. Dari hasil uji $t$, diperoleh nilai $t$ hit> $t$ tabel $(10,457>1.666)$ dan sig $<0,1 \quad(0,000<0,1)$ diperoleh, sehingga $\mathrm{Ho}_{1}$ ditolak, dan $\mathrm{Ha}_{1}$ diterima serta nilai thit. $>$ t tab $(2,815>1,661)$ dan sig $<0,1 \quad(0,006<0,1)$, sehingga $\mathrm{Ha}_{2}$ dan $\mathrm{Ho}_{2}$ diterima, sedangkan hasil uji $F$ memberi Anda nilai yang dihitung $F>F_{t a b}$, yaitu 72,760>4,84, Dan nilainya bisa dikatakan $<0,01$ atau $0,000<0,01$. $\mathrm{Ha}_{3}$ kemudian diterima, dan $\mathrm{H}_{3}$ ditolak.
\end{abstract}

Keywords: kualitas produks; harga; keputusan pembelian.

Abstract This study aims to determine the effect of product quality and price both partially and simultaneously on purchasing decisions. This type of research is associative. The population in this research is consumers who buy Boutique products with the number of samples used by 92 consumers using the incidental sampling method. In collecting data using questionnaire questionnaire distribution techniques. Data analysis method used is multiple linear regression analysis, product moment correlation coefficient, coefficient of determination and coefficient of significance test ( $t$ test and $f$ test). The results of the analysis that there is an influence both partially and simultaneously on the purchase decision which obtained the results of multiple linear regression coefficient of $Y=16,621+0.538 X 1+0.170 X 2+e$. The product moment correlation coefficient results obtained $r$ value of 0.788 . So when viewed from the interpretation table the coefficient of mass correlation is $0.60-0.79$ with a strong correlation level. The coefficient of determination results obtained $K D$ value of $62.1 \%$, this proves that the magnitude of the effect of product quality and price on consumer purchasing decisions at the Boutique of $62.1 \%$ and the rest is influenced by other factors not examined. From the $T$ Test results obtained $t$ value $>t$ table $(10.457>1.661)$ and sig $<0.1$ $(0.000<0.1)$ so that $\mathrm{Ho}_{1}$ is rejected and $\mathrm{Ha} 1$ is accepted and $t$ value $>t$ table $(2.815>1.661)$ and the value sig $<0,1(0,006<0,1)$ so that $\mathrm{Ha}_{2}$ is accepted and $\mathrm{Ho}_{2}$ while from the $\mathrm{F}$ test results can be obtained the calculated $F_{\text {value }}>f_{\text {table }}$ that is $72.760>4.84$ and sig value $<0.01$ or $0.000<0.01$. Then $\mathrm{Ha}_{3}$ is accepted and $\mathrm{HO}_{3}$ is rejected.

Keywords: product quality; price; buying decision. 


\section{A. PENDAHULUAN}

Butik ini merupakan suatu perusahaan grosir yang menjual bahan atau kain sprei, handuk, selimut, dan sprei dengan berbagai macam pilihan kualitas produk dan harga yang berbeda-beda. Butik ini sudah berdiri sejak tahun 2006, selain membuka offline store, Butik ini juga mengembangkan di beberapa media sosial seperti, Website, Instagram, Facebook, dan E-commers. Awalnya hanya mendirikan sebuah usaha sablon kaos anak yang ternyata tidak bertahan lama, namun dengan pemikiran pemikiran yang panjang, mereka berusaha untuk mengembangkan idea usaha mereka dari usaha sablon kaos anak menjadi menjual bahan atau kain sprei.

Beberapa Jenis Kualitas bahan kain sprei yang dimiliki pada Butik ini :

\section{Tabel 1.1}

Jenis Kain Sprei Yang Ada Pada Butik

\begin{tabular}{|c|c|}
\hline Jenis Kain Sprei & Keterangan Kualitas Kain Sprei \\
\hline Katun Panca & $65 \%$ katun $35 \%$ polyster, L: $240 \mathrm{~cm}, 150-200$ thread count \\
\hline Katun Jepang & $85 \%$ katun $15 \%$ polyster, L: $250 \mathrm{~cm}, 400$ thread count \\
\hline Full Katun/Dobby & $100 \%$ katun, L: $280 \mathrm{~cm} .>400$ thread count \\
\hline
\end{tabular}

Sumber:Butik

Dari Tabel diatas, disetiap katun memiliki kualitas produk yang berbeda-beda dan Butik ini memiliki pilihan kain sprei dari kualitas rendah sampai dengan kualitas terbaik. Dimana kain sprei katun panca memiliki kualitas $65 \%$ katun dan 35\% kain bahan campuran, dengan lebar $240 \mathrm{~cm}$, kain sprei katun jepang memiliki kualitas $85 \%$ katun dan $15 \%$ kain dari bahan campuran dengan lebar $250 \mathrm{~cm}$, dan untuk kain sprei full katun/dobby memiliki kualitas $100 \%$ kain dari katun dengan lebar $280 \mathrm{~cm}$. Berikut Varian motif kain sprei pada Butik ini :

Tabel 1.2

Jenis Varian Motif pada Kain Sprei Butik ini

\begin{tabular}{|c|l|c|c|c|}
\hline \multirow{2}{*}{ Tahun } & \multirow{2}{*}{ varian motif } & \multicolumn{3}{|c|}{ Jenis Kain Sprei } \\
\cline { 3 - 5 } & & Katun Panca & Katun Jepang & Full Katun/ DOBBY \\
\hline \multirow{2}{*}{2016} & Motif Dewasa & $168 /$ roll & $58 /$ roll & $3 /$ roll \\
& Motif Anak & $83 /$ roll & $15 /$ roll & - \\
\hline \multirow{2}{*}{2017} & Motif Dewasa & $154 /$ roll & $41 /$ roll & $2 /$ roll \\
& Motif Anak & $67 /$ roll & $6 /$ roll & - \\
\hline \multirow{2}{*}{2018} & Motif Dewasa & $132 /$ roll & $28 /$ roll & $1 /$ roll \\
& Motif Anak & $49 /$ roll & - & - \\
\hline
\end{tabular}

Sumber: Butik

Dari tabel 1.2 Dimana pada kain sprei katun Jepang dan full katun tidak memiliki pilihan motif yang banyak, Sehingga sebagaian konsumen tidak dapat membeli kain sprei dengan kualitas terbaik. Selain kualitas produk, harga pun sebagai pertimbangan konsumen untuk membeli suatu produk, didalam keputusan pembelian para konsumen memiliki presepsi yang berbeda-beda terhadap harga tergantung dari karakteristik pribadi (motivasi, sikap, konsep diri), latar belakang (sosial, ekonomi, demografi), pengalaman (belajar, pengetahuan), serta pengaruh lingkungannya. Harga yang ditetapkan diatas harga pesaing akan dipandang sebagai harga yang terlalu mahal, sementara harga yang ditetapkan dibawah harga pesaing akan dipandang sebagai produk yang murah atau dipandang sebagai produk yang berkualitas rendah. Dari berbagai faktor yang mempengaruhi konsumen dalam melakukan pembelian suatu produk atau jasa, biasanya konsumen selalu mempertimbangkan kualitas, harga dan produk yang sudah dikenal oleh masyarakt sbelum konsumen memutuskan untuk mbeli, Berikut macam-macam harga pada kain sprei Butik ini dan Kompetitor: 
Tabel 1.3

Daftar Harga Kain Sprei Butik ini \& Kompetitor

\begin{tabular}{|c|c|c|c|c|}
\hline Tahun & Tempat penelitian & $\begin{array}{c}\text { Katun } \\
\text { Panca/m }\end{array}$ & $\begin{array}{c}\text { katun } \\
\text { Jepang/m }\end{array}$ & $\begin{array}{c}\text { Full Katun } \\
\text { (DOBBY)/m }\end{array}$ \\
\hline \multirow{2}{*}{2016} & Butik ini & Rp. 28.000 & Rp. 40.000 & Rp. 60.000 \\
\cline { 2 - 5 } & $\begin{array}{c}\text { Pasar Cipadu / } \\
\text { Kompetitor }\end{array}$ & Rp. 27.000 & Rp. 30.000 & Rp. 50.000 \\
\hline \multirow{2}{*}{2017} & Butik ini & Rp. 30.000 & Rp. 60.000 & Rp. 80.000 \\
\cline { 2 - 5 } & $\begin{array}{c}\text { Pasar Cipadu / } \\
\text { Kompetitor }\end{array}$ & Rp. 28.000 & Rp. 45.000 & Rp. 65.000 \\
\hline \multirow{2}{*}{2018} & Butik ini & Rp. 32.000 & Rp. 60.000 & Rp. 80.000 \\
\cline { 2 - 5 } & $\begin{array}{c}\text { Pasar Cipadu / } \\
\text { Kompetitor }\end{array}$ & Rp. 30.000 & Rp. 52.000 & Rp. 75.000 \\
\hline
\end{tabular}

\section{Sumber: Butik}

Selisih harga kain sprei pada toko butik ini dibandingkan dengan kompetitor ditahun 2016 dari Rp.1.000/m hingga Rp. 10.000/m. Pada tahun 2017, selisih harga dari Rp. $2.000 / \mathrm{m}$ hingga Rp.15.000/m. Dan pada tahun 2018 terjadi selisih harga Rp. 2.000/m hingga Rp. $8.000 / \mathrm{m}$. Dari selisih yang terbilang lumayan besar, maka konsumen akan memikirkan kembali untuk mengambil keputusan pembelian pada Butik ini. Dan variasi harga yang ditawarkan oleh Butik ini dikatakan seimbang dengan kualitas produk yang didapatkan oleh konsumen. Namun kbijakan dalam penetapan harga yg dlakukan olh prusahaan masih belum optimal dibandingkan oleh pesaing, karena kebijakan yang telah diberikan oleh perusahan mash belsum bisa bersasing dengan kompetitor. Berikut tabel penjualan toko butik ini :

Tabel 1.4

Data Penjualan Butik

\begin{tabular}{|c|c|c|c|}
\hline \multirow{2}{*}{ Tahun } & Jumlah & Penjualan & \multirow{2}{*}{$\begin{array}{c}\text { Persentase } \\
\text { Penjualan }\end{array}$} \\
\cline { 2 - 2 } & Konsumen & & - \\
\hline 2014 & 1.430 & 8.680 .000 .000 & $0.94 \%$ \\
\hline 2015 & 1.376 & 8.225 .000 .000 & $0.92 \%$ \\
\hline 2016 & 1.232 & 7.630 .000 .000 & $0.92 \%$ \\
\hline 2017 & 1.150 & 7.050 .000 .000 & $0.91 \%$ \\
\hline 2018 & 1.115 & 6.482 .000 .000 & \\
\hline
\end{tabular}

Sumber: Butik

Berdasarkan tabel diatas penjualan Butik ini mengalami penurunan disetiap tahunnya, dimana butik ini memiliki penjualan tertinggi pada tahun 2014 yaitu Rp8.680.000.000 dengan jumlah konsumen yang datang 1.430 orang, dibandingkan pada tahun 2015 dengan penjualan Rp8.225.000.000 atau persentase $0.94 \%$ dengan jumlah konsumen yang datang 1.376 orang, sedangkan pada tahun 2016 dengan penjualan sebesar Rp7.630.000.000 atau persentase $0.92 \%$ dengan jumalah konsumen yang datang 1.232 orang dan pada tahun 2017 memiliki penjualan Rp7.050.000.000 atau persentase $0.92 \%$ dari penjualan sebelumnya dengan jumlah konsumen yang datang 1.150 orang, pada tahun 2018 Butik ini mengalami penurunan terendah dari tahun tahun sebelumnya yaitu dengan penjualan Rp6.482.000.000 atau persentase $0.91 \%$ dengan jumlah konsumen yang datang 1.115 orang.

Yang menjadi tujuan dalam penelitian ini adlaha menjawab pertanyaan: Apakah kualitas produk dan harga memiliki pengaruh yang positif dan signifkan terhadap keputusan pembelian baik sescara prsial ataupun smultan? 


\section{B. KAJIAN LITERATUR}

\section{Kualitas Produk:}

Menurut Kotler \& Keller (2011:121) mengatakan bahwa "Kualitas Produk adalah kemampuan suatu produk untuk melaksanakan fungsinya meliputi daya tahan, keandalan, ketepatan, kemudahan operasi dan perbaikan serta atribut lainnya".

B. Swastha (2011:65) "Kualitas mengacu pada keunggulan teknis yang sebenarnya dari produk yang dapat diverifikasi dan diukur".

\section{Harga:}

Menurut Basu S. (2010:147) "Harga adalah jumlah uang (ditambah beberapa produk kalau mungkin) yang dibutuhkan untuk mendapatkan sejumlah kombinasi dari barang beserta pelayanan". Menurut Bilson Simamora (2011:479) "Harga adalah sejumlah uang yang dikenakan atas sebuah produk atau jasa".

\section{Keputusan Pembelian:}

Menurut Kotler (2012:166) "Keputusan pembelian adalah tindakan dari konsumen untuk membeli atau tidak terhadap produk".

Menurut Fandy Tjiptono (2014:21) "keputusan pembelian adalah sebuah proses dimana konsumen mengenal masalahnya, mencari informasi mengenai produk atau merek tertentu dan mengevaluasi seberapa baik masing-masing alternative tersebut dapat memecahkan masalahnya, yang kemudian mengarah kepada keputusan pembelian".

Kerangkas Pemikiran:

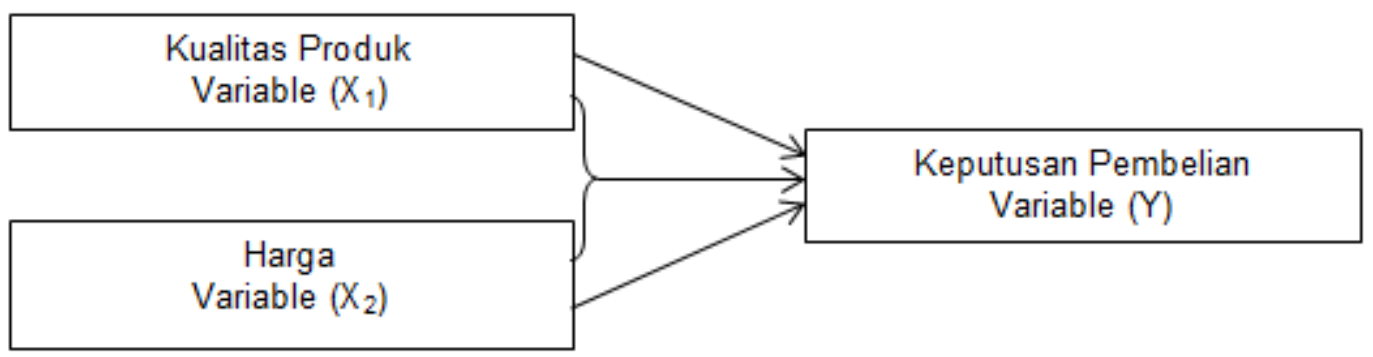

\section{Hipotesis Penelitian:}

Ha1 $: p \neq 0$ Ada pengruh positif antara kualitas produk pada keputusan pembelian

$\mathrm{Ha} 2: \mathrm{p} \neq 0$ Ada pengaruh positif antara harga terhadap keputusan pembelian

Ha3 $: p \neq 0$ Ada pngruh positif antara kualitsas produk dan har ga pada keputusan pembelian

\section{METODOLOGI PENELITIAN}

Penelitian asosiaatif, Sugiyoano (2014:44) yaitu "Penelitian yang bertujuan untuk mengetahui pengaruh atau hubungn antara dua variabel atau lebih". Populasi adalah konsaumen yang meambeli dan bertransaksi serta terdaftar sebagai pelanggan di database Butik ini pada Taahun 2018 yang baerjumlah 1.115 orang. 
Teknik sampling yang digunakan dalam penelitian ini adalah teknik Insidental Sampling dan sampel yang refpresentatif mka penulis mengambil sampel yang memiliki peluang yang sama dengan menggunakan rumus Slovin (Syofian Siregar, 2013:149), dibulatkan menjadi 92 konsumen.

Pengumpulan data mrupakan upaya yng dilakukan untk mendapatkan berbagai informasi dalam penelitian yang nantinya digunakan dalam pengukuran variable, pengumpulan data dalam penelitian ini menggunakan data primer dan data Skunder. Dimana dalam penelitian ini penulis menggunakan data primer berupa Obervasi Non Partisipan dan Kuisioner jenis tertutup dengan menggunakan skala likert. Sedangkan data skunder dalam penelitian ini menggunakan refrensi dari internet dan buku.

Analisis data dalam penelitian ini analisis deskriptif dengan cara menganallisa dengan menggunakan interval dan Uji validtas dan uji relibililtas serta uji asumsi klasik kemudian di analisis dengan analisis regresi linier berganda dan mengetahui pegaruh baik secara parsial ataupun simultan dengan uji T dan Uji 9.

\section{HASIL DAN PEMBAHASAN}

\section{Karakteristik Responden:}

Sebagian besar dari responden konsumen pada Butik ini adalah perempuan dengan $63 \%$ karna banyak konsumen perempuan yang lebih sring mmbeli keperluan sandang dan berbelanja di Butik ini dibanding dengan laki ${ }^{2}$. Responden yang membeli di Butik ini berada di sekitar pemukiman padat penduduk sehingga kebanyakan para responden Butik ini memiliki jenjang pendidikan terakhir SMA yaitu sebanyak $48 \%$. Sedangkan dari jenis pekerjaan yang paling bnyk adalah karyawan didpat presentase yaitu sebesar $34 \%$ dan paling rendah yang tidak memiliki pekerjaan dengan prosentase sebesar $2 \%$. Hal ini bahwa karyawan swasta yang banyak membeli produk di Butik ini karena biasanya membeli untuk kebutuhannya sendiri.

\section{Analisis Deskriptif Variabel: Variabel Kualitas Prduk}

Tabel 1.1

Kualitas Produk

\begin{tabular}{|c|c|c|c|c|c|c|c|c|}
\hline \multirow{3}{*}{ NO. } & \multicolumn{5}{|c|}{ ALTERNATIF JAWABAN } & \multirow{3}{*}{ Total } & \multirow{3}{*}{ Rata2 } & \multirow{3}{*}{ Ket } \\
\hline & 5 & 4 & 3 & 2 & 1 & & & \\
\hline & SS & $S$ & CK & TS & STS & & & \\
\hline 1 & 28 & 49 & 3 & 9 & 3 & 92 & 3,97 & Baik \\
\hline 2 & 24 & 47 & 10 & 7 & 4 & 92 & 3,86 & Baik \\
\hline 3 & 24 & 44 & 9 & 10 & 5 & 92 & 3,78 & Baik \\
\hline 4 & 25 & 43 & 16 & 4 & 4 & 92 & 3,91 & Baik \\
\hline 5 & 25 & 43 & 16 & 4 & 4 & 92 & 3,88 & Baik \\
\hline 6 & 27 & 49 & 9 & 4 & 3 & 92 & 4,01 & Baik \\
\hline 7 & 17 & 52 & 14 & 4 & 5 & 92 & 3,78 & Baik \\
\hline 8 & 11 & 56 & 19 & 2 & 4 & 92 & 3,73 & Baik \\
\hline 9 & 24 & 49 & 10 & 4 & 5 & 92 & 3,90 & Baik \\
\hline 10 & 10 & 63 & 11 & 5 & 3 & 92 & 3,78 & Baik \\
\hline 11 & 24 & 49 & 11 & 3 & 5 & 92 & 3,91 & Baik \\
\hline 12 & 24 & 48 & 12 & 4 & 4 & 92 & 3,91 & Baik \\
\hline Total & 261 & 601 & 131 & 62 & 49 & 1.1 & & \\
\hline Total Skor & 1.31 & 2.4 & 393 & 124 & 49 & 4.28 & 3,87 & Baik \\
\hline Presentase & 23,6 & 54,4 & 11,9 & 5,6 & 4,4 & 100 & & \\
\hline
\end{tabular}


Berdasarkan tabel diatas maka terlihat nilai rata-rata yaitu 3,87 berada di kategori skala $(3,41-4,20$ : Tinggi) dimana tanggapan responden terhadap variabel kualitas produk (x1) memiliki kategori skala tinggi atau baik, dilihat dari skor tertinggi 4,01 yaitu pada petanyaan "Produk yang dihasilkan Butik ini sesuai yang diharapkan oleh konsumen ".

\section{Variabel Harga}

Tabel 1.2

Variabel Harga

\begin{tabular}{|c|c|c|c|c|c|c|c|c|}
\hline \multirow{3}{*}{ NO. } & \multicolumn{5}{|c|}{ ALTERNATIF JAWABAN } & \multirow{3}{*}{ Total } & \multirow{3}{*}{ Rata2 } & \multirow{3}{*}{ Ket } \\
\hline & 5 & 4 & 3 & 2 & 1 & & & \\
\hline & SS & $S$ & $\mathrm{CS}$ & TS & STS & & & \\
\hline 1 & 20 & 58 & 7 & 4 & 3 & 92 & 3,95 & Baik \\
\hline 2 & 20 & 41 & 22 & 4 & 3 & 92 & 3,81 & Baik \\
\hline 3 & 18 & 45 & 21 & 7 & 1 & 92 & 3,78 & Baik \\
\hline 4 & 18 & 48 & 15 & 8 & 3 & 92 & 3,76 & Baik \\
\hline 5 & 18 & 54 & 14 & 4 & 2 & 92 & 3,89 & Baik \\
\hline 6 & 15 & 50 & 21 & 2 & 4 & 92 & 3,76 & Baik \\
\hline 7 & 21 & 57 & 8 & 3 & 3 & 92 & 3,97 & Baik \\
\hline 8 & 25 & 48 & 11 & 4 & 4 & 92 & 3,93 & Baik \\
\hline 9 & 15 & 44 & 23 & 6 & 4 & 92 & 3,65 & Baik \\
\hline 10 & 15 & 58 & 16 & 2 & 1 & 92 & 3,91 & Baik \\
\hline 11 & 31 & 49 & 8 & 3 & 1 & 92 & 4,15 & Baik \\
\hline 12 & 16 & 65 & 8 & 2 & 1 & 92 & 4,01 & Baik \\
\hline Total & 234 & 617 & 174 & 49 & 30 & 1.104 & & \\
\hline Total Skor & 1.17 & 2.468 & 522 & 98 & 30 & 4.288 & 3,88 & Baik \\
\hline Presentase & 21,1 & 55,8 & 15,8 & 4,4 & 2,7 & 100 & & \\
\hline
\end{tabular}

Sumber: Analis Data

Berdasarkan tabel diatas maka terlihat nilai rata-rata yaitu 3,88 berada di kategori skala (3,41 - 4,20: Tinggi) dimana tanggapan responden terhadap variabel harga (x2) memiliki kategori skala tinggi atau baik, dilihat dari skor tertinggi 4,07 yaitu pada pertanyaan " Syarat pembayaran tidak rumit dan dapat dirundingkan kedua belah pihak." sehingga banyak responden yang memilih Butik ini sebagai toko yang sangat menyediakan pembayaran dengan menggunakan Transfer antar Bank, ATM, kita tahu selama ini banyak butik yang tidak menyediakan mesin EDC ATM namun Butik ini kali ini menyediakan mesin EDC ATM untuk konsumen yang bertransaksi dengan menggunakan kartu agar sangat mudah dan aman tentunya. Ini yang menjadi kelebihan Butik ini dibandingkan dengan butik yang lainnya dengan memudahkan syarat bertransaksi konsumen akan lebih efisien dalam berbelanja di Butik ini.

Disamping itu pihak perusahaan harus lebih memperhatikan harga jual produk dari segi "Pembayaran dapat sesuaikan dengan pesanan yang akan diproduksi terlebih dahulu." dimana diperoleh skor terendah 3,65. Maka dari itu perusahaan harus memperhatikan kembali pesanan yang ada pada produk di Butik ini karena konsumen merasa pembayaran melalui Dp setengah dari jumlah totalan pesanan. Namun alangkah baiknya Butik ini lebih memperhatikan yang ditetapkan terutama harus memperhatikan bahan yang digunakan karena konsumen merasa Produk yang di jual oleh Butik ini lebih mahal jika dibandingkan dengan butik yang lainnya dengan kualitas yang sama. 
Variabel Keputusan Pembelian

Tabel 1.3

Variabel Keputusan

\begin{tabular}{|c|c|c|c|c|c|c|c|c|}
\hline \multirow{3}{*}{ NO. } & \multicolumn{5}{|c|}{ ALTERNATIF JAWABAN } & \multirow{3}{*}{ Total } & \multirow{3}{*}{ Rata2 } & \multirow{3}{*}{ Ket } \\
\hline & 5 & 4 & 3 & 2 & 1 & & & \\
\hline & SS & $S$ & $\mathrm{CS}$ & TS & STS & & & \\
\hline 1 & 21 & 52 & 7 & 7 & 5 & 92 & 3,83 & Baik \\
\hline 2 & 18 & 54 & 11 & 5 & 4 & 92 & 3,83 & Baik \\
\hline 3 & 24 & 53 & 3 & 8 & 4 & 92 & 3,92 & Baik \\
\hline 4 & 15 & 59 & 12 & 4 & 2 & 92 & 3,88 & Baik \\
\hline 5 & 26 & 52 & 9 & 2 & 3 & 92 & 4,04 & Baik \\
\hline 6 & 39 & 45 & 5 & 2 & 1 & 92 & 4,29 & Baik \\
\hline 7 & 17 & 61 & 13 & 0 & 1 & 92 & 4,01 & Baik \\
\hline 8 & 15 & 63 & 12 & 1 & 1 & 92 & 3,97 & Baik \\
\hline 9 & 35 & 49 & 4 & 3 & 1 & 92 & 4,23 & Baik \\
\hline 10 & 0 & 77 & 11 & 3 & 1 & 92 & 3,78 & Baik \\
\hline 11 & 16 & 44 & 27 & 3 & 2 & 92 & 3,75 & Baik \\
\hline 12 & 16 & 50 & 20 & 6 & 0 & 92 & 3,82 & Baik \\
\hline Total & 242 & 659 & 134 & 44 & 25 & 1.104 & & \\
\hline Total Skor & 120 & 2.636 & 402 & 88 & 25 & 4.361 & 3,95 & Baik \\
\hline Presentase & 21,9 & 59,69 & 12 & 4 & 2,26 & 100 & & \\
\hline
\end{tabular}

Sumber: Analis Data

Berdasarkan tabel diatas maka terlihat nilai rata-rata yaitu 3,95 atau di bulatkan 3,95 berada di kategori skala $(3,41-4,20$ : Baik) dimana tanggapan responden terhadap variabel keputusan pembelian (y) memiliki kategori skala tinggi atau baik, dilihat dari skor tertinggi 4,29 yaitu pada pernyataan "Butik ini menjadi alternatif pilihan konsumen dalam berbelanja" hal ini membuktikan bahwa banyak konsumen yang mencari alternatif tentang produk yang di jual oleh Butik ini dari orang terdekat ataupun media social. Konsumen mencari informasi tentang bahan dan ketahanan yang diberikan oleh Butik ini karena konsumen telah selektif membeli produk dan mencari informasi sebanyak-banyaknya tentang produk yang di jual sebelum melakukan keputusan pembelian.

\section{Uji Validitas dan Uji Reliabilitas}

Tabel 1.4

Uji Validitas

\begin{tabular}{|c|c|c|c|c|}
\hline No & $\times 1$ & $\times 2$ & Y & r Tab \\
\hline 1 & 0,825 & 0,836 & 0,814 & 0,172 \\
\hline 2 & 0,725 & 0,786 & 0,774 & 0,172 \\
\hline 3 & 0,658 & 0,842 & 0,760 & 0,172 \\
\hline 4 & 0,852 & 0,833 & 0,781 & 0,172 \\
\hline 5 & 0,802 & 0,759 & 0,821 & 0,172 \\
\hline 6 & 0,813 & 0,766 & 0,631 & 0,172 \\
\hline 7 & 0,870 & 0,767 & 0,625 & 0,172 \\
\hline 8 & 0,838 & 0,790 & 0,623 & 0,172 \\
\hline 9 & 0,823 & 0,706 & 0,643 & 0,172 \\
\hline 10 & 0,781 & 0,264 & 0,455 & 0,172 \\
\hline 11 & 0,721 & 0,396 & 0,471 & 0,172 \\
\hline 12 & 0,793 & 0,343 & 0,337 & 0,172 \\
\hline
\end{tabular}

Jur Sumber: Analis Data 
Untuk mengolah uji validitas, tiap butir pertanyaan, dilakukan dengan membandingkan nilai $r$ hitung dengan $r$ tabel. Nilai $r$ tabel dalam peenelitian ini dengan 92 responden adalah 0,172 dengan taraf signifikansi $\alpha=0,1(10 \%)$ dengan tingkat kepercayaan pengujiannya adalah 90\%. Variabel kualitas produk (X1), Harga (X2) dan Keputusan Pembelian (Y) diperoleh nilai $r$ hitung berada di atas angka 0,172 atau ( $\left.r_{\text {hitung }}>r_{\text {tabel }}\right)$, maka semua item dinyatakan valid. Untuk itu kuesioner yang digunakan layak untuk diolah sebagai data penelitian.

Tabel 1.5

Hasil Analisa Uji Reliabilitas

\begin{tabular}{|c|l|c|c|c|}
\hline No & \multicolumn{1}{|c|}{ Variabel } & $\begin{array}{c}\text { Alpha } \\
\text { Cronvach }\end{array}$ & Syarat & Keterangan \\
\hline 1 & Kualitas Produk $\left(\mathrm{X}_{1}\right)$ & 0,945 & 0,6 & Reliabel \\
\hline 2 & Harga $\left(\mathrm{X}_{2}\right)$ & 0,899 & 0,6 & Reliabel \\
\hline 3 & Keputusan Pembelian $(\mathrm{Y})$ & 0,876 & 0,6 & Reliabel \\
\hline
\end{tabular}

Sumber: Analis Data

Berdasarkan tabel diatas dapat disimpulkan bahwa seluruh pernyataan dalam kuesioner dikatakan reliabel dan baik sehingga dapat digunakan dalam penelitian ini dan sejalan dengan teori Sugiyono (2013:184) suatu instrumen dinyatakan Reliabel apabila koefisien reliabelnya Alpha Cronbach minimal 0,6.

\section{Uji Asumsi Klasik \\ Uji Normalitas:}

Tabel 1.6

Uji Normalitas Kolmogrov-Smirnov Test One-Sample Kolmogorov-Smirnov Test

\begin{tabular}{|ll|r|}
\hline \multicolumn{1}{|c|}{} & & $\begin{array}{c}\text { Unstandardize } \\
\text { d Residual }\end{array}$ \\
\hline Normal Parametersa,b & Mean & 92 \\
& Std. Deviation & $0 E-7$ \\
Most Extreme & Absolute & -069 \\
Differences & Positive & -045 \\
Kolmogorov-Smirnov Z & Negative & -.069 \\
Asymp. Sig. (2-tailed) & & -664 \\
\hline
\end{tabular}

a. Test distribution is Normal.

b. Calculated from data.

Sumber: Analis Data 
Berdasarkan tabel diatas maka dapat dilihat nilai Asymp. Sig (2-Tailed) yaitu 0,770 sehingga lebih besar dari 0,1 atau 0,770 $>0,1$, maka data pada penelitian ini berdstribusi normal.

\section{Uji Multikolinearitas}

Tabel 1.7

Hasil output SPSS uji Multikoliniearitas

Coefficients $^{\mathrm{a}}$

\begin{tabular}{|c|c|c|c|c|c|c|c|c|}
\hline \multirow{2}{*}{\multicolumn{2}{|c|}{ Model }} & \multicolumn{2}{|c|}{$\begin{array}{l}\text { Unstandardized } \\
\text { Coefficients }\end{array}$} & \multirow{2}{*}{$\begin{array}{c}\begin{array}{c}\text { Standardized } \\
\text { Coefficients }\end{array} \\
\text { Beta }\end{array}$} & \multirow{2}{*}{$t$} & \multirow{2}{*}{ Sig. } & \multicolumn{2}{|c|}{$\begin{array}{c}\text { Collinearity } \\
\text { Statistics }\end{array}$} \\
\hline & & B & $\begin{array}{l}\text { Std. } \\
\text { Error }\end{array}$ & & & & Tolerance & VIF \\
\hline 1 & (Constant) & 16,621 & 3,062 & & 5,427 &, 000 & & \\
\hline & $\begin{array}{l}\text { Kualitas } \\
\text { Produk }\end{array}$ &, 538 & ,051 & ,712 & 10,457 &, 000 &, 920 & 1,087 \\
\hline & Harga & , 170 &, 060 & , 192 & 2,815 &, 006 &, 920 & 1,087 \\
\hline
\end{tabular}

a. Dependent Variable: Keputusan Pembelian

Sumber: Analis Data

Dari data tabel di atas maka diperoleh nilai:

a. Tolerance Value Kualitas Produk 0,920 > 0.1 dan VIF Kualitas Produk 1,087 < 10.0

b. Tolerance Value Harga Jual Produk 0,920 > 0.1 dan VIF Harga 1,087 $<10.0$

Maka bebas dari adanya multikolinearitas dan semua variabel bebas yang dipakai dalam penelitian ini lolos gelaja multikolinearitas.

\section{Regresi Linier Berganda}

Berdasarkan tabel di atas diperoleh persamaan regresi berganda sebagai berikut:

$Y=16,621+0,538 X_{1}+0,170 X_{2}+e$

Persamaan regresi tersebut mempunyai makna sebagai berikut:

a. Konstanta sebesar 16,621 menyatakan bahwa tanpa ada variabel kualitas produk $\left(x_{1}\right)$ dan harga $\left(x_{2}\right)$ maka keputusan pembelian $(y)$ tetap terbentuk sebesar 16,621 atau jika nilai kualitas produk $\left(\mathrm{x}_{1}\right)$ dan harga $\left(\mathrm{x}_{2}\right)$ nilainya $=0$ maka keputusan pembelian tetap memiliki nilai $=16,621$. Yang artinya konsumen akan tetap membeli produk di Butik ini meskipun kualitas produk dan harga yang diberikan masih kurang, karena pada dasarnya komsumen membeli produk di Butik ini karena untuk keperluannya.

b. Variabel kualitas produk $\left(x_{1}\right)$ berpengaruh positif terhadap keputusan pembelian $(y)$ dengan nilai koefisien sebesar 0,538 . Artinya jika variabel kualitas produk $\left(x_{1}\right)$ meningkat satu-satuan dengan asumsi bahwa variabel harga $\left(\mathrm{x}_{2}\right)$, tetap, maka keputusan pembelian (y) akan meningkat sebesar 0,538.

c. Variabel harga $\left(\mathrm{x}_{2}\right)$ berpengaruh positif terhadap keputusan pembelan $(\mathrm{y})$ dengan nilai koefisien sebesar 0,170 . Artinya jika variabel harga $\left(\mathrm{x}_{2}\right)$ meningkat satu-satuan dengan asumsi bahwa variabel kualitas produk $\left(\mathrm{x}_{1}\right)$ tetap, maka keputusan pembelian akan meningkat sebesar 0,170.

\section{Uji Hipotesis (Uji t)}


Berdasarkan tabel 1.7 maka pengaruh dari masing-masing variabel $\mathrm{x}_{1}$ (kualitas produk) dan $\mathrm{x}_{2}$ (harga) terhadap keputusan pembelian (y) dapat dilihat dari arah tanda dan tingkat signifikansi (probablitas) dimana semua variabel mempunyai arah yang positif dan berpengaruh signifikan karena nlai signifkansi $<0,1$. atau pada $t$ tabel dengan nilai signifkasi 0,1 maka diperoleh $t$ tabel 1,661

a. Pengaruh Kualitas Produk $\left(x_{1}\right)$ terhadap keputusan pembelian Hasil uji parsial (uji $t$ ) antara kualitas produk terhadap keputusan pembelian menunjukan nilai $t$ hitung $>t$ tabel $(10,457>1,661)$ dan sig $<0,1 \quad(0,000<0,1)$ sehingga Ho di tolak dan Ha diterima yaitu "terdapat pengaruh kualitas produk Terhadap Keputusan Pembelian Konsumen Butik ini " Hal ini sejalan dengan penelitian yang dilakukan oleh Jackson R.S, (2013) dalan jurnal EMBA dengan judul " Kualitas Produk, Harga, Promosi, dan Kualitas Pelayanan Terhadap Keputusan Pembelian Spring Bed Comforta dimna Kualitas produk memilikipengaruh terhadapkeputusan.

b. Pengaruh harga $\left(\mathrm{x}_{2}\right)$ terhadap keputusan pembelian Hasil uji parsial (uji $\mathrm{t}$ ) antara harga terhadap keputusan pembelian menunjukan nilai $t$ hitung $>t$ tabel $(2,815>1,661)$ dan nilai sig $<0,1(0,006<0,1)$ sehingga Ha diterima dan Ho ditolak yaitu "terdapat pengaruh harga Terhadap Keputusan Pembelian Konsumen Butik ini " Hal ini sejalan dengan penelitian yang dilakukan oleh Lidya Mongi (2014) dalam Jurnal EMBA dengan judul Kualitas Produk, Strategi Promosi dan Harga Terhadap Pembelian Kartu dimana harga meilikipengaruh terhadap keputusan.

\section{Uji Hipotesis (Uji F)}

Uji statistik $\mathrm{F}$ pada dasarnya menunjukan apakah semua variabel independen yang dimasukan dalam model mempunyai pengaruh secara bersama-sama terhadap variabel dependenya. Hasil perhitungan Uji F dapat dilihat pada tabel:

Tabel 1.8

Hasil Uji F (simultan)

ANOVA $^{a}$

\begin{tabular}{|rl|r|r|r|r|r|}
\hline \multicolumn{1}{|l|}{ Model } & \multicolumn{1}{c|}{$\begin{array}{c}\text { Sum of } \\
\text { Squares }\end{array}$} & \multicolumn{1}{c|}{ df } & $\begin{array}{c}\text { Mean } \\
\text { Square }\end{array}$ & $\mathrm{F}$ & Sig. \\
\hline \multirow{4}{*}{1} & Regression & 2339.369 & 2 & 1169.685 & 72.760 & $.000^{\mathrm{b}}$ \\
& Residual & 1430.750 & 89 & 16.076 & & \\
& Total & 3770.120 & 91 & & & \\
\hline
\end{tabular}

a. Dependent Variable: Keputusan Pembelian

b. Predictors: (Constant), Harga, Kualitas Produk

Sumber: Analis Data

Dari hasi uji $F$ dapat diperoelh nilai $F_{\text {hitung }}>F_{\text {tabel yaitu } 72,760>4,84}$ dan nilai sig $<0,01$ atau $0,000<0,01$ " terdapat pengaruh kualitas produk dan harga secara simultan Terhadap Keputusan Pembelian Konsumen Butik ini ". Hasil penelitian ini sejalan dengan penelitian yang dilakukan oleh Rifqi Sulthan (2018), dan Zulaica (2016). 


\section{E. KESIMPULAN}

1. Kualitas produk berpengaruh positif dan signifikan terhadap keputusan pembelian dilihat dari hasil pengujian hipotesis $t$ hitung $>t$ tabel $(10,457>1,661)$ dan sig $<0,1$ $(0,000<0,1)$.

2. Harga berpengaruh positif dan signifikan terhadap keputusan pembelian dilihat dari hasil pengujian hipotesis diperoleh nilai $t$ hitung $>t$ tabel $(2,815>1,661)$ dan nilai sig $<$ $0,1(0,006<0,1)$.

3. Kualitas produk dan harga jual berpengaruh positif dan signifikan terhadap keputusan pembelian dilihat dari hasil pengujian hipotesis diperoleh nilai $F$ hitung $>F$ tabel yaitu $72,760>4,84$ dan nilai sig $<0,01$ atau $0,000<0,01$,

\section{DAFTAR PUSTAKA}

Arianto, Nurmin. 2018. Pengaruh Kualitas Produk dan Kelengkapan Produk Terhadap Keputusan Pembelian Produk Salt n Pepper Pada PT Mitra Busana Sentosa Bintaro. KREATIF: Jurnal IImiah Prodi Manajemen Universitas Pamulang 6 (2), 143-154.

Arianto,Nurmin. 2018. Pengaruh Kualitas Produk Dan Harga Terjadap Keputusan Pembelian Smartphone Pada Samsung Store Mall Bintaro Exchange. JIMF (Jurnal IImiah Manajemen Forkamma) 1 (3).

Bilson, Simamora. 2011. Memenangkan Pasar Dengan Pemasaran Efektif Dan Profitabel. Jakarta: PT Gramedia Pustaka Utama

Dharmmesta, Basu Swastha. 2011. Materi Pokok Manajemen Pemasaran, Edisi Kedua Cetakan Pertama. Jakarta: Universitas Terbuka

Kotler, Philip and Kevin Lane Keller, 2011. Manajemen Pemasaran, Edisi 13 Jilid 1 dan 2, Alih Bahasa : Bob Sabran, Erlangga, Jakarta.

Kotler, Philip, 2012, Manajemen Pemasaran, Edisi 12, Jilid 1, Erlangga, Jakarta.

Kotler, Philip, dan Gary Armstrong 2012. Prinsip-prinsip Pemasaran. Edisi 13. Jilid 1. Erlangga : Jakarta.

Siregar, Syofian. 2013. Metode Penelitian Kuantitatif. Jakarta: PT Fajar Interpratama Mandiri.

Sugiyono. 2012. Metode Penelitian Kuantitatif Kualitatif dan R\&D. Bandung: Alfabeta.

Sugiyono. 2013. Metode Penelitian Pendidikan Pendekatan Kuantitatif, Kualitatif, dan R\&D. Bandung: Alfabeta.

Sugiyono. 2014. Metode Penelitian Pendidikan Pendekatan Kuantitatif, Kualitatif, dan R\&D. Bandung: Alfabeta.

Swastha,Basu. 2010.Manajemen Penjualan: Pelaksanaan Penjualan, BPFEYogyakarta

Tjiptono, Fandy. 2014, Pemasaran Jasa - Prinsip, Penerapan, dan Penelitian, Andi Offset, Yogyakarta. 